\title{
Penerapan Metode Presentasi Dalam Topik Deskripsi NKRI Untuk Pembelajaran PKn Bagi Siswa Kelas IX SMP Negeri 3 Palopo
}

\section{Malyana}

SMP Negeri 3 Palopo

+62 853-9925-9510

\section{Abstrak}

Warga negara perlu memiliki pengetahuan kewarganegaraan yang baik, memiliki keterampilan intelektual maupun partisipatif, dan pengetahuan serta keterampilan dalam membentuk suatu karakter atau watak yang mapan, sehingga menjadi sikap dan kebiasaan sehari-hari. Namun dalam kenyataan yang dihadapi dalam pengajaran Pendidikan Kewarganegaraan (PKN), kebanyakan guru mengeluhkan rendahnya kemampuan siswa berfikir secara rasional, kritis dan kreatif, sehingga kurang mampu memahami berbagai wacana kewarganegaraan. Penelitian ini bertujuan memperbaiki rendahnya pemahaman siswa Negara Kesatuan Republik Indonesia dalam pembelajaran pendidikan kewarganegaraan bagi siswa Kelas IX SMP Negeri 3 Palopo. Penelitian ini merupakan Classroom Action Research yang dilaksanakan dengan mengikuti prosedur penelitian yang mencakup kegiatan perencanaan (planning), tindakan (action), observasi (observation), dan refleksi (reflection) atau evaluasi. Penulis merencanakan pembelajaran dengan memilih materi pembelajaran tentang Negara Kesatuan Republik Indonesia (NKRI) melalui dua siklus. Hasil penelitian ini menunjukkan bahwa dalam penerapan metode presentasi pada siklus I, skor pemahaman materi NKRI yang dicapai siswa berada dalam kategori tinggi dengan nilai rata-rata 70,26 . Pada siklus II, walaupun secara kategori tetap sama tetapi skor pemahaman materi siswa kelas meningkat sebesar 74,47. Dengan demikian disimpulkan bahwa keaktifan siswa dalam mengikuti kegiatan pembelajaran pendidikan kewarganegaraan menjadi lebih baik.

Kata Kunci: presentasi, NKRI, pembelajaran PKn

\section{Pendahuluan}

Pendidikan Kewarganegaraan (PKN) bertujuan untuk membentuk watak warga negara yang baik, yaitu warganegara yang tahu, mau, dan sadar akan hak serta kewajibannya. Untuk meningkatkan kemampuan dan kemauan siswa dalam pembelajaran PKN, perlu adanya penerapan pembelajaran yang sesuai. Dengan penerapan pembelajaran yang sesuai diharapkan hasil belajar siswa menjadi meningkat dan lebih baik.

Visi mata pelajaran pendidikan kewarganegaraan adalah terwujudnya suatu mata pelajaran yang berfungsi sebagai sarana pembinaan watak bangsa (nation and character building) dan pemberdayaan warga negara. Rumusan tersebut sejalan dengan aspek-aspek kompetensi yang hendak dikembangkan dalam pembelajaran pendidikan kewarganegaraan. Aspek-aspek kompetensi tersebut mencakup pengetahuan kewarganegaraan (civic knowledge), keterampilan kewarganegaraan (civic skills), dan watak atau karakter kewarganegaraan (civic dispositions). 
Hal tersebut sejalan dengan konsep Benjamin S. Bloom tentang pengembangan kemampuan siswa yang mencakup ranah kognitif, psikomotor, dan afektif. Aspek kompetensi pengetahuan kewarganegaraan menyangkut kemampuan akademik yang dikembangkan dari berbagai teori atau konsep politik, hukum, dan moral. Secara lebih terperinci, materi pengetahuan pendidikan kewarganegaraan meliputi pengetahuan tentang hak dan tanggung jawab warga negara, hak asasi manusia, prinsip-prinsip dan proses demokrasi, lembaga pemerintah dan non pemerintah, identitas nasional, pemerintahan berdasar hukum dan peradilan yang bebas dan tidak memihak, konstitusi, serta nilai-nilai dan norma-norma dalam masyarakat.

Keterampilan kewarganegaraan meliputi keterampilan intelektual dan keterampilan berpartisipasi dalam kehidupan berbangsa dan bernegara. Contoh keterampilan intelektual adalah keterampilan dalam merespon berbagai persoalan politik, misalnya merancang dialog dengan anggota partai politik. Contoh keterampilan berpartisipasi adalah keterampilan menggunakan hak dan kewajiban di bidang hukum, misalnya segera melapor kepada polisi atas tindakan kejahatan yang diketahui.

Watak atau karakter kewarganegaraan sesungguhnya merupakan materi yang paling substantif dan esensial dalam mata pelajaran pendidikan kewarganegaraan. Dimensi ini dapat dipandang sebagai muara dari pengembangan kedua dimensi sebelumnya.

Dengan demikian seorang warga negara pertama-tama perlu memiliki pengetahuan kewarganegaraan yang baik, memiliki keterampilan intelektual maupun partisipatif, dan pada akhirnya pengetahuan serta keterampilan itu akan membentuk suatu karakter atau watak yang mapan, sehingga menjadi sikap dan kebiasaan sehari-hari. Watak yang mencerminkan warga negara yang baik itu misalnya sikap religius, toleran, jujur, adil, demokratis, taat hukum, menghormati orang lain, memiliki kesetiakawanan sosial dan lain-lain.

Namun kenyataan yang dihadapi dalam pengajaran pendidikan kewarganegaraan (PKN) kebanyakan guru mengeluhkan rendahnya kemampuan berfikir secara rasional, kritis dan kreatif, sehingga mampu memahami berbagai wacana kewarganegaraan. Pencapaian yang diperoleh dengan menerapkan metode penugasan, skor pemahaman siswa termasuk dalam kategori tinggi dan secara kuantitas mengalami peningkatan. Sebagai pembanding, bagaimana atau perubahan apa yang akan terjadi bila siswa diajari topik Negara Kepulauan Republik Indonesia (NKRI) melalui metode presentasi.

Penelitian ini dilaksanakan bukan hanya untuk mengembangkan pemahaman tetapi juga kemampuan peserta didik dalam menerapkan prinsip-prinsip kewarganegaraan dengan baik, serta siswa mampu mengemukakan pendapatnya. Oleh karena itu, siswa dengan rasional, kritis dan kreatif, dapat mengembangkan dan melestarikan nilai luhur dan moral yang berakar pada budaya bangsa Indonesia yang diharapkan dapat diwujudkan dalam bentuk perilaku kehidupan sehari-hari peserta didik sebagai individu, anggota masyarakat dalam kehidupan berbangsa dan bernegara.

Untuk itu, dalam proses pembelajaran pun diperlukan pembelajaran yang efektif agar bagi siswa yang belajar pendidikan kewarganegaraan (PKN) mudah memahami prinsip-prinsip kewarganegaraan dengan baik. Nantinya, siswa dapat menghubungkan antara pengetahuan yang dimilikinya dengan penerapannya dalam kehidupan mereka sebagai anggota keluarga dan masyarakat. Dengan konsep ini hasil pembelajaran diharapkan lebih bermakna bagi siswa. Proses pembelajaran berlangsung alamiah dalam bentuk kegiatan siswa bekerja dan mengalami, bukan transfer pengetahuan dari guru ke siswa. 
Untuk mencapai sasaran dari pelaksanaan penelitian ini, metode presentasi dipilih sebagai cara untuk melaksanakan pembelajaran pendidikan kewarganegaraan (PKN). Prinsip dari pendekatan ini adalah meningkatkan pemahaman yang lebih mendalam, retensi lebih lama, meningkatkan kebaikan budi, kepekaan, dan toleransi, terutama dalam berargumen untuk menjelaskan rasional suatu permasalahan yang diberikan.

Dari prinsip-prinsip tersebut diharapkan tingkat penerimaan siswa terhadap proses pembelajaran menjadi lebih baik. Karena itu pula wacana kewarganegaraan yang berkaitan dengan Negara Kesatuan Republik Indonesia dapat dibicarakan bersama berdasarkan tugas yang diberikan.

Berdasarkan permasalahan di atas, maka tujuan penelitian tindakan ini adalah untuk memperbaiki rendahnya pemahaman siswa Negara Kesatuan Republik Indonesia dalam pembelajaran pendidikan kewarganegaraan bagi siswa Kelas IX SMP Negeri 3 Palopo.

Untuk mencapai sasaran dari pelaksanaan penelitian ini, metode presentasi dipilih sebagai cara untuk melaksanakan pembelajaran pendidikan kewarganegaraan (PKN). Prinsip dari metode ini adalah meningkatkan pemahaman dan kemampuan berargumen siswa yang lebih mendalam, retensi lebih lama, meningkatkan kebaikan budi, kepekaan, dan toleransi.

Dari prinsip-prinsip tersebut diharapkan tingkat penerimaan siswa terhadap proses pembelajaran menjadi lebih baik. Karena itu pula wacana kewarganegaraan yang berkaitan dengan Negara Kepulauan Republik Indonesia (NKRI) dapat dibicarakan bersama dalam kelompoknya dimana menempatkan diri berdasarkan prinsip-prinsip pendekatan tersebut.

\section{Metode Penelitian}

Objek tindakan dalam penelitian ini adalah pemahaman siswa tentang Negara Kesatuan Republik Indonesia yang ditingkatkan dengan penerapan metode presentasi. Jenis penelitian yang dikembangkan adalah penelitian tindakan kelas (Classroom Action Research) dengan tahapan-tahapan pelaksanaan meliputi: perencanaan, pelaksanan tindakan, observasi, dan evaluasi serta refleksi secara langsung.

Kelas IX berjumlah 23 siswa, 11 orang laki-laki dan 12 orang perempuan di IX SMP Negeri 3 Palopo Kota Palopo. Kemampuan akademik siswa masih terbatas karena motivasi belajar siswa yang rendah. Situasi kelas saat pembelajaran masih belum optimal, siswa masih belum seluruhnya mempunyai keaktifan dalam belajar.

\section{Prosedur Penelitian}

Penelitian ini merupakan Penelitian Tindakan Kelas (Classroom Action Research) yang dilaksanakan dengan mengikuti prosedur penelitian berdasarkan pada prinsip Kemmis dan Taggart (1988) yang mencakup kegiatan perencanaan (planning), tindakan (action), observasi (observation), refleksi (reflection) atau evaluasi. Keempat kegiatan ini berlangsung secara berulang dalam bentuk siklus.

Penulis merencanakan pembelajaran pendidikan kewarganegaraan (PKN) dengan memilih materi pembelajaran tentang Negara Kesatuan Republik Indonesia (NKRI) melalui dua siklus pada semester 2 . Alokasi waktu yang digunakan pada siklus pertama terdiri dari $2 \times 40$ menit. 


\section{Siklus Penelitian}

\section{Siklus 1}

Planning

1. Menganalisis Silabus/ Kurikulum Tingkat Satuan Pendidikan.

2. Menyusun Rencana Pelaksanaan Pembelajaran dengan metode presentasi.

3. Merancang model pembelajaran klasikal.

4. Mendiskusikan penerapan model pembelajaran interaktif.

5. Menyiapkan instrumen (angket, pedoman observasi, tes akhir).

6. Menyusun kelompok belajar peserta didik.

7. Merencanakan tugas kelompok.

\section{Action}

1. Melaksanakan langkah-langkah sesuai perencanaan.

2. Menerapkan model pembelajaran klasikal.

3. Melakukan pengamatan terhadap setiap langkah-langkah kegiatan sesuai rencana.

4. Memperhatikan alokasi waktu yang ada dengan banyaknya kegiatan yang dilaksanakan.

5. Mengantisipasi dengan melakukan solusi apabila menemui kendala saat melakukan tahap tindakan.

Observation

1. Melakukan diskusi dengan guru dan kepala sekolah untuk rencana observasi.

2. Melakukan pengamatan terhadap penerapan model pembelajaran klasikal yang dilakukan guru kelas IX.

3. Mencatat setiap kegiatan dan perubahan yang terjadi saat penerapan model pembelajaran klasikal.

4. Melakukan diskusi dengan guru untuk membahas tentang kelemahan-kelemahan atau kekurangan yang dilakukan guru serta memberikan saran perbaikan untuk pembelajaran berikutnya.

\section{Reflection}

1. Menganalisis temuan saat melakukan observasi pelaksanaan observasi.

2. Menganalisis kelemahan dan keberhasilan guru saat menerapkan model pembelajaran klasikal dan mempertimbangkan langkah selanjutnya.

3. Melakukan refleksi terhadap penerapan model pembelajaran klasikal.

4. Melakukan refleksi terhadap kreativitas peserta didik dalam pembelajaran pendidikan kewarganegaraan (PKN).

5. Melakukan refleksi terhadap hasil belajar peserta didik.

\section{Siklus 2}

Planning

1. Mengevaluasi hasil refleksi, mendiskusikan, dan mencari upaya perbaikan untuk diterapkan pada pembelajaran berikutnya.

2. Mendata masalah dan kendala yang dihadapi saat pembelajaran.

3. Merancang perbaikan berdasarkan refleksi siklus 1 . 
Action

1. Melakukan analisis pemecahan masalah.

2. Melaksanakan tindakan perbaikan dengan menggunakan penerapan metode presentasi.

Observation

1. Melakukan pengamatan terhadap penerapan metode presentasi.

2. Mencatat perubahan yang terjadi.

3. Melakukan diskusi membahas masalah yang dihadapi saat pembelajaran dan memberikan balikan.

\section{Reflection}

1. Merefleksikan proses pembelajaran yang dilakukan.

2. Merefleksikan hasil belajar peserta didik dengan penerapan metode presentasi.

3. Menganalisis temuan dan hasil akhir penelitian.

4. Menyusun rekomendasi.

Dari tahap kegiatan pada siklus 1 dan 2, hasil yang diharapkan adalah agar (1) peserta didik memiliki kemampuan dan kreativitas serta selalu aktif terlibat dalam proses pembelajaran pendidikan kewarganegaraan (PKN); (2) guru memiliki kemampuan merancang dan menerapkan model pembelajaran interaktif dengan kerja kelompok khusus pada mata pelajaran Matematika, dan (3) terjadi peningkatan prestasi peserta didik pada mata pelajaran Matematika.

\section{Instrumen}

Pengamatan yang dilakukan secara kolaboratif yang melibatkan guru mata pelajaran yang sejenis sebagai pengamat di kelas ini menggunakan instrumen penelitian tes hasil belajar, lembar observasi dan lembar cek list, dan lembar kerja siswa sebagai evaluasi atau penilaian. Data hasil belajar yang terkumpul dianalisis dengan menggunakan analisis kualitatif dan analisis secara kuantitatif dengan menggunakan statistika deskriptif. Sedangkan data tentang hasil pengamatan dan tanggapan siswa dianalisis secara kualitatif dengan menggunakan teknik kategorisasi standar

\section{Analisis dan Refleksi}

Analisis yang digunakan dalam penelitian ini adalah memanfaatkan analisa deskriptif kuantitatif dari proses dan hasil belajar. Analisis juga dilakukan dari hasil observasi. Analisis berdasarkan siklus yang secara bertahap. Analisis 1 dalam siklus 1 yang hasilnya direfleksikan ke siklus 2. Refleksi yang dilakukan sesuai dengan perencanaan yang dilakukan. Penelitian dengan metode metode presentasi ini, peneliti berharap siswa akan menjadi lebih termotivasi dalam proses pembelajaran. Tindak lanjut dalam penelitian ini siswa dapat menjadi lebih aktif dan metode presentasi akan dilakukan secara berkesinambungan oleh guru.

\section{Hasil Penelitian}

\section{Deskriptif Laporan Tindakan Siklus I}

Metode presentasi sebagai cara yang digunakan dalam kegiatan pembelajaran pendidikan kewarganegaraan telah dilaksanakan, untuk mengetahui seperti apa yang diperoleh selama pelaksanaan tindakan ini dikemukakan data hasil pengamatan sebagai berikut. 
Tabel 1. Deskripsi Hasil Tindakan Siklus I

\section{Statistics}

Nilai Siklus 1

\begin{tabular}{|l|l|}
\hline N $\quad$ Malid & 38 \\
Mean & 0 \\
Median & 70.2632 \\
Mode & 70.0000 \\
Std. Deviation & 70.00 \\
Variance & 4.34140 \\
Minimum & 18.848 \\
Maximum & 60.00 \\
\hline
\end{tabular}

Tabel ini menunjukkan skor pemahaman yang diperoleh siswa pada siklus I, rata-rata pemahaman yang dicapai siswa pada siklus I ini adalah 70,26. Berdasarkan petunjuk pengkategorian, skor ini termasuk kategori tinggi. Seperti yang dapat kita lihat kalau pemahaman siswa dengan materi NKRI telah diawali dengan pencapaian skor yang termasuk tinggi. Berkaitan dengan tabel di atas, tabel 2 berikut menunjukkan secara detail skor peragaan yang dinilai selama siklus I.

Tabel 2. Skor Pemahaman Anak Didik Selama Tindakan Siklus I

Nilai Siklus 1

\begin{tabular}{|ll|l|l|l|l|}
\hline & & & & & Cumulative \\
Valid & 60.00 & 1 & 2.6 & 2.6 & 2.6 \\
& 65.00 & 8 & 21.1 & 21.1 & 23.7 \\
& 70.00 & 19 & 50.0 & 50.0 & 73.7 \\
75.00 & 8 & 21.1 & 21.1 & 94.7 \\
& 80.00 & 2 & 5.3 & 5.3 & 100.0 \\
& Total & 38 & 100.0 & 100.0 & \\
\hline
\end{tabular}

Walaupun secara klasikal, terlihat bahwa pemahaman siswa termasuk kategori baik. Namun, sebaran skor yang dicapai individu siswa menunjukkan bahwa sekitar kurang lebih 9 orang diantaranya termasuk dengan pemahaman berkategori sedang. Sisanya, kurang lebih 29 orang diantaranya termasuk dengan pemahaman berkategori tinggi.

\section{Deskriptif Laporan Tindakan Siklus II}

Tindakan yang dilakukan pada siklus II adalah melanjutkan penerapan metode presentasi untuk topik NKRI, dibandingkan dengan hasil yang dicapai pada siklus I untuk itu ditunjukkan hasil selama pelaksanaan tindakan pada siklus II sebagai berikut. 
Tabel 3. Deskripsi Hasil Tindakan Siklus II

\section{Statistics}

Nilai Siklus 2

\begin{tabular}{|c|c|c|}
\hline \multirow[t]{2}{*}{$N$} & & \\
\hline & Missing & 0 \\
\hline \multicolumn{2}{|c|}{ Mean } & 74.4737 \\
\hline \multicolumn{2}{|c|}{ Median } & 75.0000 \\
\hline \multicolumn{2}{|c|}{ Mode } & 75.00 \\
\hline \multicolumn{2}{|c|}{ Std. Deviation } & 5.66992 \\
\hline \multicolumn{2}{|c|}{ Variance } & 32.148 \\
\hline \multicolumn{2}{|c|}{ Minimum } & 60.00 \\
\hline \multicolumn{2}{|c|}{ Maximum } & 90.00 \\
\hline
\end{tabular}

Tabel ini menunjukkan skor pemahaman yang diperoleh siswa pada siklus II, rata-rata pemahaman yang dicapai siswa pada siklus II ini adalah 74,47. Berdasarkan petunjuk pengkategorian, skor ini termasuk kategori tinggi. Seperti yang dapat kita lihat kalau pemahaman siswa dengan materi NKRI telah mengalami peningkatan skor secara kuantitas. Berkaitan dengan tabel di atas, tabel 4 berikut menunjukkan secara detail skor pemahaman yang dinilai selama siklus I.

Tabel 4. Skor Peragaan Anak Didik Selama Tindakan Siklus I

Nilai Siklus 2

\begin{tabular}{|ll|l|l|l|l|}
\hline & & & & & Cumulative \\
Valid & 60.00 & 1 & 2.6 & 2.6 & 2.6 \\
& 70.00 & 14 & 36.8 & 36.8 & 39.5 \\
& 75.00 & 15 & 39.5 & 39.5 & 78.9 \\
& 80.00 & 4 & 10.5 & 10.5 & 89.5 \\
& 85.00 & 3 & 7.9 & 7.9 & 97.4 \\
& 90.00 & 1 & 2.6 & 2.6 & 100.0 \\
& Total & 38 & 100.0 & 100.0 & \\
\hline
\end{tabular}

Walaupun secara klasikal, terlihat bahwa pemahaman siswa termasuk kategori baik. Namun, sebaran skor yang dicapai individu siswa masih menunjukkan bahwa terdapat 1 orang diantaranya termasuk dengan pemahaman berkategori sedang. Sisanya, kurang lebih 37 orang diantaranya termasuk dengan pemahaman berkategori tinggi.

\section{Pembahasan}

\section{Pembahasan dan Refleksi Siklus}

\section{Pembahasan Siklus}

Selama berlangsungnya penelitian dari Siklus I sampai Siklus II, tampak jelas bahwa perubahan tersebut adalah peningkatan skor pemahaman tentang topik NKRI dalam pelajaran PKN pada siswa yang dijadikan subjek. Selain itu juga terlihat sejumlah perubahan-perubahan yang terjadi pada keaktifan siswa dalam mengikuti proses belajar mengajar. Perubahanperubahan tersebut merupakan data kuantitatif yang diperoleh dari lembar observasi pada setiap pertemuan yang dicatat oleh guru selama penelitian berlangsung. Secara kualitas 
pembelajaran, penerapan metode presentasi juga memberikan perubahan terhadap hasil belajar siswa. Perubahan-perubahan yang dimaksud adalah:

1. Antusiasme siswa mengikuti kegiatan pembelajaran, ditunjukkan dengan jumlah siswa yang hadir pada setiap pertemuan tidak mengalami penurunan yang berarti. Hal ini terlihat dari jumlah siswa yang mengikuti kegiatan pembelajaran paling sedikit 35 orang dari jumlah yang ideal sebanyak 38 orang.

2. Siswa yang memperhatikan materi pelajaran, dalam pelaksanaan penelitian, komponen ini cukup meragukan sebab hampir seluruh siswa kurang meminati topik NKRI. Akan tetapi, hasil observasi menunjukkan bahwa jumlah siswa cukup memperhatikan materi pelajaran yang diberikan. Hal ini mencapai puncaknya pada pertemuan IV (pada siklus I) dan pertemuan II dan III (pada siklus II).

3. Siswa yang mengajukan diri untuk mengajukan pendapat selama sesi diskusi dilakukan. Pada tiap pertemuan sebelum pelaksanaan penelitian, siswa enggan untuk berpendapat dan lebih memilih diam, disebabkan mereka kurang termotivasi dan tidak memahami dengan baik cara berpendapat yang baik dan benar. Dengan penerapan metode presentasi memberikan perubahan motivasi belajar siswa, salah satu perubahan itu tampak dari kemauan mereka untuk mengajukan diri dalam menyampaikan pendapat yang dimiliki. Hasil observasi menunjukkan paling banyak 5 orang dan paling rendah 3 orang, berarti selama kegiatan pembelajaran diterapkan menggunakan metode presentasi, siswa semakin memahami tujuan pembelajaran yang ingin dicapai.

4. Siswa yang mempresentasekan hasil diskusi kelompok sebagai perwakilan kelompok, dan siswa yang menjawab pertanyaan atau tanggapan kelompok lain pada presentase hasil kelompok, mengalami peningkatan yang positif. Sehingga tampak diskusi pembelajaran berlangsung menarik, serta siswa merasa senang dengan kegiatan pembelajaran yang dilakukan dengan menerapkan metode presentasi.

5. Komponen selanjutnya yang diobservasi adalah siswa yang menyelesaikan tugas atau pekerjaan rumah tepat waktu, untuk komponen ini siswa menunjukkan dengan perubahan yang meningkat dengan positif. Salah satu aspek yang tumbuh dari antusias siswa adalah kesadaran belajar mereka menjadi semakin tinggi.

Dari perubahan-perubahan yang telah dipaparkan di atas dapat disimpulkan bahwa motivasi siswa dalam mengikuti pembelajaran dari siklus I ke siklus II meningkat. Selain itu, pemahaman tentang topik NKRI dalam pelajaran PKN yang meningkat memacu antusias siswa dalam belajar pendidikan kewarganegaraan.

Selain itu, kegiatan menarik yang ditunjukkan siswa diantaranya, keinginan mereka untuk memperbaiki tugas-tugas dilakukan dengan bertanya atau berdiskusi dengan temannya. Bahkan terdapat sejumlah siswa yang mendatangi guru di luar jam pelajaran pendidikan kewarganegaraan baik di sekolah maupun di rumah untuk menanyakan materi yang kurang dipahami.

\section{Analisis Refleksi Siklus}

\section{Refleksi Siklus I}

Pada awal pertemuan berikutnya, yaitu pertemuan kedua dari siklus I dimana proses pembelajaran dengan metode presentasi dimulai, siswa dikelompokkan ke dalam 6 kelompok belajar yang dibentuk berdasarkan pemerataan tingkat kemampuan siswa. Selanjutnya barulah dimulai pembelajaran dimana guru berperan membimbing siswa untuk menemukan sendiri 
beberapa konsep dasar dari materi yang sedang dipelajari kemudian menuliskannya di lembar kerja siswa terpadu. Setelah setiap kelompok selesai menuliskan hasil penemuan mereka, diberikan kesempatan kepada tiap kelompok untuk mempresentasikan hasil kerja kelompok mereka, sementara kelompok lain menanggapinya.

Pada pertemuan ini diskusi kurang berjalan lancar. Hal ini dimungkinkan mengingat proses belajar mengajar yang sedang berlangsung berbeda dengan metode pembelajaran sebelumnya. Masih banyak siswa yang enggan dan takut mengemukakan pertanyaan dan tanggapan. Tindakan yang diberikan untuk mengatasi permasalahan tersebut adalah membimbing siswa untuk berani mengemukakan pendapatnya sendiri dan menekankan kepada siswa untuk tidak takut salah dalam belajar.

Pada pertemuan ketiga dan keempat, pembelajaran tetap dilakukan dengan metode presentasi yang dipadukan dengan tanya jawab, dan diskusi, dimana pada awal pertemuan tugas (PR) dikumpulkan. Sebelum memulai pembelajaran, guru kembali mengingatkan materi yang telah dibahas pada pertemuan sebelumnya. Pada pertemuan ketiga dan keempat ini sudah nampak adanya perubahan keaktifan siswa meskipun belum seberapa seperti keberanian untuk tampil mempresentasikan hasil kerja kelompoknya, mulai ada tanggapan atau pertanyaan dari siswa, selain itu sudah nampak persaingan antar kelompok dalam mempresentasikan hasil kerja kelompok mereka meskipun pada akhirnya sampai pada konsep yang sama sehingga diskusi sudah mulai berjalan lancar meskipun belum maksimal seperti yang diinginkan.

\section{Refleksi Siklus II}

Untuk siklus II ini terdapat lima kali pertemuan, yang terdiri dari empat kali pertemuan untuk pembahasan materi dan satu kali pertemuan untuk tes hasil belajar. Pelaksanaan siklus II pada dasarnya sama dengan pelaksanaan siklus I.

Seperti halnya siklus I, semua pertemuan pada siklus II ini pembelajarannya dilakukan dengan metode presentasi yang dipadukan dengan metode tanya jawab, dan diskusi. Pada siklus II ini perhatian siswa semakin memperlihatkan peningkatan. Hal ini ditandai dengan semakin banyaknya siswa yang aktif mengajukan pertanyaan untuk materi yang kurang dimengerti serta memberikan tanggapan pada saat pembahasan soal secara bersama.

Pada siklus II ini kemampuan siswa memahami materi semakin baik, jika sebelumnya suatu materi yang kurang dimengerti dan disenangi siswa harus dijelaskan berulang-ulang, maka pada siklus II ini sebagian besar siswa sudah langsung menangkap atau dengan cepat memahami materi dengan sekali atau dua kali penjelasan. Selain itu keaktifan siswa bekerja bersama dalam kelompoknya serta keaktifan siswa dalam menyelesaikan soal-soal latihan lebih meningkat. Peningkatan yang terjadi pada siklus II dapat dilihat dari peningkatan rata-rata pemahaman siswa setelah diadakan tes akhir siklus II.

\section{Tanggapan Siswa}

\section{Pelajaran Pendidikan Kewarganegaraan Secara Umum}

Sebagian siswa yang lain menyenangi topik NKRI itu relatif, dalam artian adakalanya disukai apabila materinya dianggap menyenangkan dan adakalanya merasa bosan jika materinya panjang. Sebagian siswa yang lain menyukai mata pelajaran pendidikan kewarganegaraan karena pendidikan kewarganegaraan sangat menantang dan menuntut kita aktif mendalaminya, serta materi pendidikan kewarganegaraan itu apabila sudah benar-benar dipahami maka soal yang bagaimanapun akan mudah dikerjakan. 


\section{Penerapan Pembelajaran Kontekstual pada Mata Pelajaran Pendidikan Kewarganegaraan}

Pada umumnya siswa senang dengan penerapan pembelajaran dengan metode presentasi karena mereka lebih mudah memahami materi karena penyajian materi selalu dikaitkan dengan lingkungan atau konteks siswa. Selain itu dengan metode presentasi, khususnya kegiatan pembelajaran yang dilakukan secara berkelompok, siswa merasa lebih santai menerima materi karena topik yang dibahas dapat dibicarakan secara bersama dengan teman lain dalam kelompoknya.

\section{Saran Perbaikan Proses Pembelajaran Pendidikan Kewarganegaraan}

1. Sebagian siswa menyarankan agar dalam penyajian materi hendaknya disajikan dengan serinci-rincinya atau sejelas-jelasnya.

2. Sebagian siswa yang lain menyarankan untuk lebih banyak membahas soal-soal pada setiap pertemuan dengan tujuan supaya mereka terbiasa dan terlatih mengerjakan soal.

3. Sebagian siswa yang lain menyarankan untuk menggunakan banyak sumber buku dalam pembelajarannya sehingga siswa tidak terpaku pada satu buku saja dalam belajar.

4. Sebagian siswa ada juga yang menyarankan agar guru yang mengajar harus lebih mengerti dan memahami siswa yang dihadapinya.

\section{Kesimpulan}

Berdasarkan penjelasan yang dikemukakan sebelumnya, dapat ditarik beberapa kesimpulan penelitian ini bahwa penerapan metode presentasi pada siklus I, skor pemahaman materi NKRI yang dicapai siswa Kelas IX SMP Negeri 3 Palopo Kota Palopo yang diperoleh berada dalam kategori tinggi dengan nilai rata-rata 70,26. Pada siklus II, walaupun secara kategori tetap sama tetapi skor pemahaman materi siswa kelas meningkat sebesar 74,47. Namun, perlu ditekankan bahwa sedikit lebih baik metode presentasi diterapkan dalam kegiatan pembelajaran PKN dimana perubahan tersebut terlihat dari skor klasikal yang diperoleh.

Keaktifan siswa dalam mengikuti kegiatan pembelajaran pendidikan kewarganegaraan menjadi lebih baik. Hal ini dipengaruhi prinsip metode yang menekankan kemampuan siswa untuk mengemukakan pendapatnya sehingga secara tidak langsung mendukung mereka untuk belajar lebih baik sebelum mempresentasikan materi tersebut.

Oleh karena itu, maka disarankan untuk menerapkan metode presentasi sebagai salah satu cara dalam memperbaiki pemahaman materi siswa. Disarankan juga bagi para orang tua siswa untuk turut membantu guru dalam membina dan mendidik anaknya serta membantu mengingatkan anaknya untuk senantiasa belajar di rumah dan mengerjakan tugas pekerjaan rumah mereka. Bagi siswa, disarankan untuk senantiasa mengulangi pelajaran di rumah dan juga mengerjakan tugas-tugas mereka serta tidak ragu-ragu untuk menanyakan hal-hal yang kurang dimengertinya dalam pelajaran baik pada guru maupun pada teman-teman yang bisa membantu.

\section{Referensi}

Depdiknas. (2003). Kerangka dasar pengembangan silabus dan sistem penilaian hasil belajar siswa SLTP berbasis Kompetensi, Jakarta: Depdiknas, Direktorat Jenderal pendidikan Dasar dan Lanjutan Pertama.

Julianti. (2002). Peningkatan pembelajaran kontekstual sebaga upaya peningkatan hasil belajar matematika siswa kelas II SLTP Negeri 5 Sinjai Selatan. Skripsi FMIPA UNM. 
Nurhadi. (2002). Proyek peningkatan mutu SLTP, Jakarta: Depdiknas, Direktorat Jenderal pendidikan Dasar dan Lanjutan Pertama.

Nurhadi, B., \& Senduk, A. G. (2003). Pembelajaran Kontekstual (Contextual Teaching and Learning/CTL) dan penerapannya dalam KBK. Malang: Universitas Negeri Malang.

Slameto. (1995). Belajar dan Faktor-Faktor yang mempengaruhinya. Jakarta: Rineka Cipta.

Sudjana, N. (1996). Cara Belajar Siswa Aktif dalam Proses Belajar Mengajar. Bandung: Sinar Baru Algesindo.

Sudjana, N. (1895). Penilaian Hasil Proses Belajar Mengajar. Bandung: Remaja Rosdakarya. 